\title{
Unseasonable April Winter Disastrous To Early Migrants
}

MAN, BIRD and GOD

I go to prove my soul!

I see my way as birds their trackless way.

I shall arrive! What time, what circuit first

$I$ ask not; but unless God sends his hail

Or blinding fireballs, sleet or stifling snow,

In some time, his good time I shall arrive;

He guides me and the bird. In his good time!

\section{ROBERT BROWNING}

The sending of the "Blue Jay" material to the press was delayed for a week, in order that we could get reports of damage to bird life as a result of the severe weather during the last week in April. The following observations from various parts of the province tell the story. These are preceded by the excellent general report by Fred G. Bard, Director of the Provincial museum of Natural History.
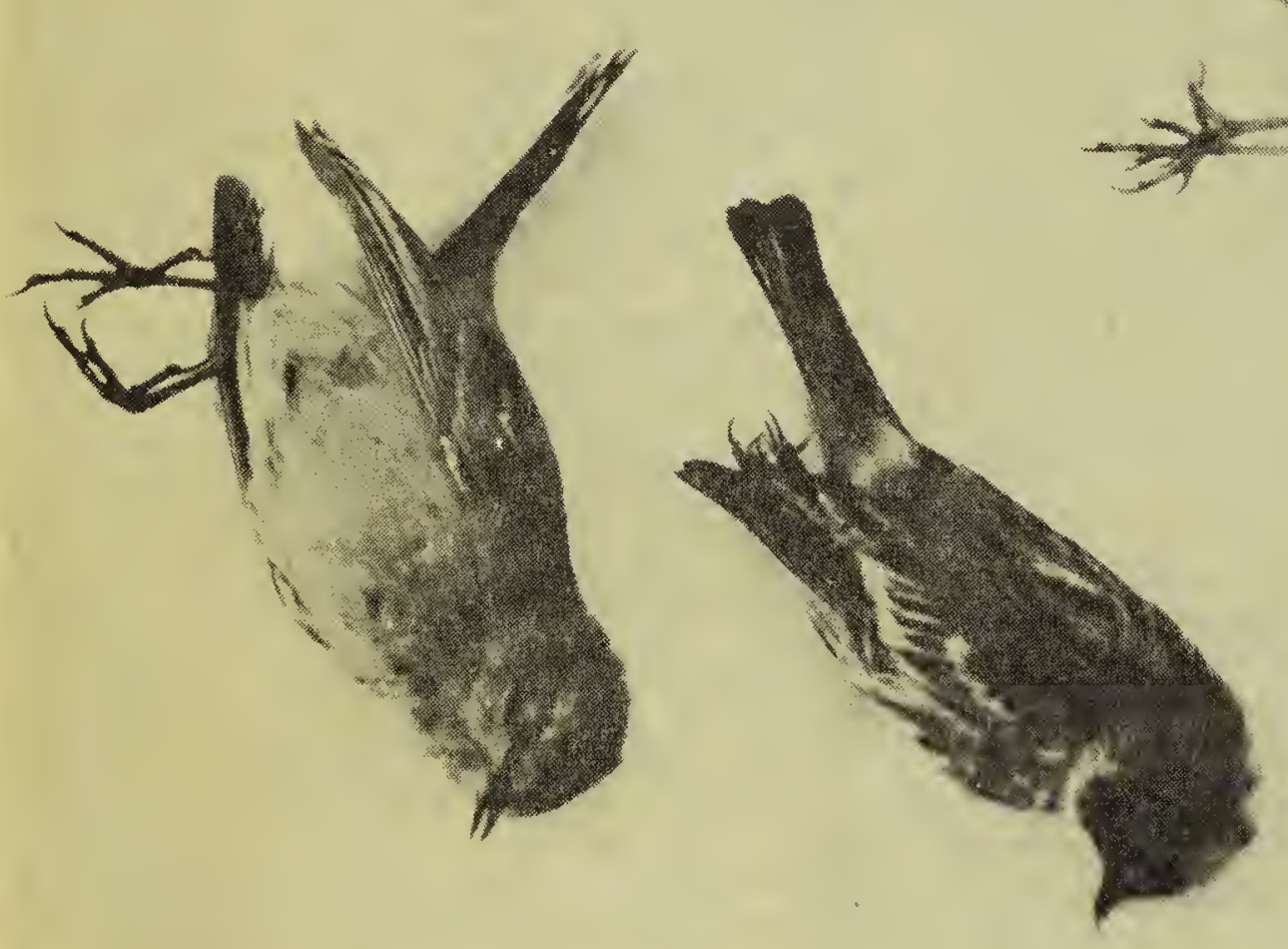

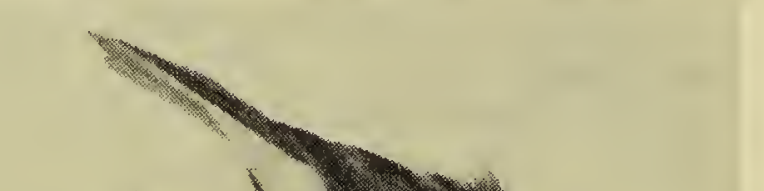

American Pipit, Myrtle Warbler., Savannah Sparrow

\section{FRED G. BARD}

We have witnessed the effects of an unusually severe return of winter. It covered an eleven day period, with 8.1 inches of snow and temperatures established new all time records.

One of the first reports I received was from a downtown worker. While crossing the lane in the city center he saw two Robins along with House Sparrows scurry out of a garbage container. This brought the serious- ness of the situation home - I contacted a local radio station and an appeal was breadcast asking people to keep a spot swept clean of snow and place bird seed and bread out for the birds.

On April 27th, the Eared, Horned and Pied-billed Grebes arrived and on the 28th Wascana Lake froze over, and the same day the first flight of Tree Swallows was seen about the Health Building about 6.20 p.m. They hovered around the window ledges 
for a place to settle. The next morning the snow was deeper and it was colder than ever. We looked around but saw no sign of the Swallows. Most of us think the birds just left and somehow were able to survive. The Tree Swallow's plight, hovering around the windows, came back to me as Miss Elizabeth Barker told me the story of finding 8 dead Tree Swallows in one small area, and 14 in her search to determine the storm's extent. Other species Miss Barker found were 1 American Pipit, 1 Hermit Thrush, 2 Myrtle Warblers, and 1 Black-crowned Night Heron.

We found 2 Tree Swallows, 3 Myrtle Warblers, 1 Orange-crowned, 1 American Pipit, 2 Savannah Sparrows, 1 Killdeer \& 1 Hermit Thrush. We picked up two Swans injured from the high winds that preceded the storm and later some boys brought in a Mallard Duck with a broken wing. Children at St. Michael's School in Regina found a dead Great Blue Heron.

Our two nesting pair of Canada Geese had the first egg frozen. From then on we visited the marsh twice a day to salvage the eggs being layed each day.

Reports from Frankslake tell of Ducks freezing to the ice and many found dead in the days that followed.

Walter Scott of Kedleston telephoned to report two Whooping Cranes at Rowan's Bay on April 29th in company with Ducks, Geese, Swans and Pelicans, and on checking the next day all but a few Ducks were gone. We do not know what became of the many thousands of waterfowl some of which had nests and were laying. Walter also states, quote "Unusual and varied as our weather may be, never have I observed it give our migrating birds (the insectivorous ones particularly) such a harrowing reception as they received during the close of April."

Ralph Stueck of Abernethy, says on looking out of the window one morning he saw a Warbler as well as House Sparrows hovering like a Hummingbird around an icicle formed on a maple tree injury. He was able to obtain a moving picture as evidence of this unusual sight. Imagine this Warbler trying to feed from the few drops of sap that would run from the icicle?
Mr. McFadden of the Normal Apartments put out bread for a onelegged Robin to feed on - this Robin has been there for the last three summers.

Ranchers in the Cypress Hills lost many new born calves in spite of quick rescue work. It was impossible to get around even with tractorshorseback was the only way and this aid came too late for many of the newborn calves found later buried beneath the snow.

This storm was in no sense a blizzard - just a heavy wet snow storm that dropped to sub zero temperatures. Such severe weather as this period covered could easily destroy a large percentage of our few remaining Whooping Cranes. Some of the Cranes were in the area we speak of. We know twenty-four started north but not until next winter following the count in Texas will we know the success or loss for the 1954 season. The most recent news of Whooping Cranes comes from $\mathrm{Mr}$. Wade, News Editor of the Saskatoon Star-Phoenix; their staff photographer took three photographs of three Whooping Cranes on May 5 th at Pike Lake 18 miles south west of Saskatoon. I have since seen a copy of the photographs, and while out of focus, the Cranes can be identified. We are more than happy these three are in apparent good health and they could easily be our "Tardy trio." photographed at Herbert November 5th, 1953. The same three were the last to leave the refuge in Texas April 19 th of this year. Let's get together to publicize their value and launch a campaign to allow them safe passage during the hunting seasons!

We have little photographic evidence of this storm but the accompanying photos will illustrate some of the tragic effects. We would like our readers to report personal observations and those of friends, providing names and locations.

Through the courtesy of the Meteorological Service we have the statistics covering this last storm quote:

"April 1954 was much colder than normal over Southern Saskatchewan, and indeed, over the prairies in general. Regina's mean temperature during April 1954 was $+30.4^{\circ}$ as against a normal of $+38^{\circ}$. 
Especially bad were the last ten days, when strong, cold winds from the north were the rule, and heavy snowfalls occurred. Night-time temperatures, as well as day-time, were far below normal during this period (see table.)

A mild February and average March conspired to rid the prairies of almost all their snow cover by April 8th so that the ground was mostly bare for the middle two weeks of April. On April 17th and 19th traces of snow fell. The heaviest subsequent falls of snow were as follows (at Regina - these are typical of South Saskatchewan, Estevan, Broadview, Swift Current, Saskatoon, Dafoe and Yorkton).

$\begin{array}{ccc}\text { April 21st } & - & 1 . " \\ \text { April 23rd } & - & 1 / 2 " \\ \text { April 27th } & - & 1.4^{\prime \prime} \\ \text { April 28th } & - & 3.3^{\prime \prime} \\ \text { April 29th } & - & 1.8 " \\ \text { April 30th } & - & 1 / 10^{\prime \prime} \\ \text { Total } & & 8.1 "\end{array}$

In addition to this a heavy fall of 9" occurred at Estevan on the 21st.

Total Regina snowfall for April was 8.8" as against a normal snowfall of $3.1^{\prime \prime}$. This snow is only now melting and running off.

\section{Table of Regina Temperatures}

\section{Day}

Day Night Day Nighi (actual 1954) (normal)

* April 15 April 16

* April 17

* April 18 April 19

April 20 April 21

* April 22

* April 23 April 24

* April 25 April 26

April 27

April 28

April 29

April 30

May 1

May 2

May 3

$\begin{array}{llll}48 & 27 & 49 & 26 \\ 62 & 22 & 50 & 26 \\ 48 & 33 & 50 & 27 \\ 41 & 24 & 51 & 27 \\ 45 & 16 & 52 & 28 \\ 36 & 29 & 52 & 28 \\ 39 & 20 & 53 & 28 \\ 50 & 24 & 53 & 29 \\ 40 & 32 & 54 & 29 \\ 42 & 28 & 55 & 30 \\ 50 & 33 & 55 & 30 \\ 30 & 30 & 56 & 30 \\ 25 & 17 & 56 & 31 \\ 26 & 25 & 57 & 31 \\ 28 & 11 & 57 & 31 \\ 28 & -1 & 58 & 32 \\ 28 & 19 & 58 & 32 \\ 36 & 21 & 59 & 33 \\ 37 & 14 & 59 & 33\end{array}$

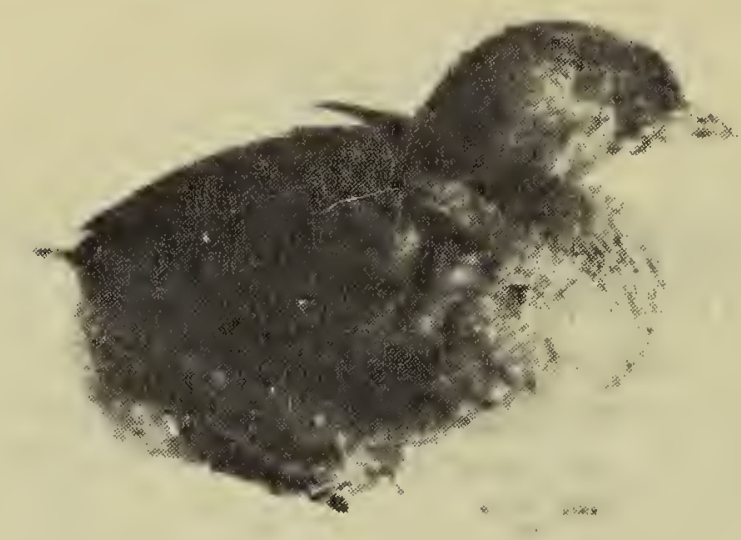

- Photo by Fred Bord

Pied-billed Grebe, unable to fly after being forced down in storm.

The night-time temps on April 29-30th and May 2-3rd were the lowest ever recorded; the previous record lows were $+3^{\circ}$ (1909) and $+16.5^{\circ}$ (1907) respectively.

The day-time temperatures on the 26 th, 27th and 28th were the coldest ever recorded. Previous coldest temperatures on these dates were $33.5^{\circ}$ (1907) $30^{\circ}$ (1907) and $28^{\circ}$ (1907) respectively.

\section{The Black Swallow-tail}

\section{Mrs. Ellen Averill}

In one of the "Blue Jay" books of last year I saw an inquiry from Viceroy, Sask., as to whether anyone had seen the larva of the Black Swallowtail Butterfly. Just about that time I found on the parsnip row in our garden some large caterpillars - I believe they were bright green with some colored markings, stripes and spots of black and pink, though I'm not positive about this. However, I was curious as to what butterfly they would become. I placed four or five in a cracked quart sealer, replaced the glass top with a double piece of cotton mosquito net, held in place by the screw top, and placed the jar in a shady spot on the veranda and fed the larvae with fresh parsnip leaves every day. In due time they pupated and later hatched into Black Swallow-tail Butterflies. 